\title{
Photobacteriosis Exchange between Wild and Farmed Fish in the Mediterranean Area
}

\section{Monique Mancuso*}

Institute for Coastal Marine Environment (IAMC)-National Research Council (CNR)-Section of Messina, Italy

\begin{abstract}
Photobacteriosis appeared for the first time in the Mediterranean area in 1990 causing heavy losses in fish-farms and affecting also the open sea. It affects several fish species, the aetiological agent is Photobacterium damselae subsp. piscicida. The disease is influenced by climatic changes and depends from the age of fish. The bacterium may survive in water and sediment for one month and can entry in a viable but nonculturable (VBNC) state and moreover may be transmitted to fish through water using the skin as a portal to entry. The potential exchange of pathogens between farmed and wild fish is already object of debate. Great efforts are necessary to better understand the dynamics of the disease and monitoring plans and facilities management.
\end{abstract}

Keywords: Disease diffusion; Fish interaction; Photobacterium Damselae Subsp.Piscicida

\section{Introduction}

Photobacteriosis, or "fish Pasteurellosis", first appeared in the Mediterranean area in 1990 causing heavy losses in fish-farms and affecting also the open sea. It represents a serious bacterial disease affecting: Dicentrarchus labrax, Sparus aurata, Mugilidae, Atherina spp., Pagrus major, Dentex dentex and Solea solea in the Mediterranean area [1-5] causing severe losses.

The disease is influenced by climatic changes and depends from the age of fish [6]. Fish diseased show external slight haemorrhagic areas in gills and head, internally whitish tubercles in the target organs (spleen and Kidney), haemorrhagic septicaemia may occur.

The halophilic, Gram negative, coccobacillus, Photobacterium damselae subsp. piscicida is the aetiological agent. This bacterium may survive in water and sediment for one month at $20^{\circ} \mathrm{C}$ and show the capacity to entry in a viable but non culturable state [7]; and it may be transmitted to fish through water and using the skin as a portal to entry [8].

The potential exchange of pathogens between farmed and wild fish is inevitable and the development of rapid identification methods for bacterial disease has been suggested to limit damages $[5,9,10]$. In the past few decades, there has been a worldwide emergence and intensification of marine diseases affecting economically and ecologically important species.

Efforts are continuously being made to reduce the risks of pathogen transmission from aquaculture sites to spreading wild populations.

Likewise, there is a risk of diseases spreading from wild to farmed fish, with subsequent proliferation and spread of pathogens in the farms as well as into the environment. In fact wild adult fish, as a mullets, could may act as reservoirs (i.e. presenting a chronic form of the disease) and when there are favorable the environmental conditions reactivate the pathogen provoking outbreaks of the disease [11].

However, current debates are not always funded on facts and there is a need in both the fisheries and aquaculture industries for an overview of knowledge in this field [12].

In Italy were reported various outbreaks of disease with possible interaction between both wild and farmed fish.
In the summer of 1990 was reported a severe episode of Photobacteriosis involving Mugil cephalus and Liza aurata populations of Magra river (La Spezia) [13].

Since 2006 to present [14] there has been a recurrence of Photobacteriosis, especially in wild mullets, with reports of massive mortality in areas adjacent to river mouths (Magra and Garigliano) or in the vicinity of harbours (Genoa), simultaneously also in other parts of the Mediterranean basin are occurring severe episodes of mortality (Spain and Greece).

Great effort has been invested in the last few years in the study of Photobacterium damselae subsp. piscicida, a bacterium that can serve as a model for the study of any bacterial fish pathogen. Although some aspects of this complex disease and its etiological agent are not yet fully understood, the global extent of this disease and the enormous economic losses it causes will constitute an important impetus to further our knowledge of the patho-biological characteristics of this microorganism [15].

On september 2008 a daily reported the presence of hundreds dead mullets along the coasts of the riparian and bordering the nearby Abruzzo and whose cause has been attributed to Photobacteriosis.

It is assumed that the fish analyzed can be considered as reservoirs of the test organism, whose environmental persistence is an important factor to be considered among the causes of outbreaks.

In comparison to other geographic regions there is a lack of scientific information and data relating to disease interactions and pathogen exchange between the wild fauna and Mediterranean aquaculture.

Hard evidence for transmission between wild and farmed fish exists

*Corresponding author: Monique Mancuso, Institute for Coastal Marine Environment (IAMC)-National Research Council (CNR)-Section of Messina, Spianata S. Raineri 86, Italy, E-mail: monique.mancuso@iamc.cnr.it

Received October 07, 2012; Accepted October 09, 2012; Published October 17 2012

Citation: Mancuso M (2012) Photobacteriosis Exchange between Wild and Farmed Fish in the Mediterranean Area. J Aquacult Res Dev 3:e102 doi:10.4172/21559546.1000e102

Copyright: (c) 2012 Mancuso M. This is an open-access article distributed under the terms of the Creative Commons Attribution License, which permits unrestricted use, distribution, and reproduction in any medium, provided the original author and source are credited. 
Citation: Mancuso M (2012) Photobacteriosis Exchange between Wild and Farmed Fish in the Mediterranean Area. J Aquacult Res Dev 3:e102 doi:10.4172/2155-9546.1000e102

Page 2 of 2

only for streptococcosis (Streptococcus iniae) and fish tuberculosis (Mycobacterium marinum), in the Red Sea; in addition Vibriosis and Photobacteriosis are currently studied. The high abundance of susceptible wild fish species in the vicinity of sea bream and sea bass net-pens raises questions on the potential local effects. The reverse aspect is also highly relevant, as these local populations may constitute reservoirs of these bacteria to the farmed populations.

The role of disease interactions in amplifying and geographical spread of these bacteria in the sea is hypothesised, but has not been adequately studied as of yet.

Minimizing disease interaction is an essential element of any biosecurity programme (e.g. through effluent disinfection) to reduce the likelihood of exposure, establishment and the consequences.

The planning of new aquaculture facilities needs take into account disease interaction between wild and farmed populations. Efforts are continuously being made to reduce the risks of pathogen transmission from aquaculture sites and there is great concern about the potential effects of diseases spreading to wild populations.

To survey wild fish populations, it is necessary to apply methods with high sensitivity to be able to detect low levels of pathogens.

Today, methods for detection of pathogens are PCR-based methods [16], in particular Real Time PCR [17]. These assays are sensitive methods, but they cannot distinguish between nucleic acids from viable and non-viable pathogens, from vaccine components and free residual bacterial nucleic acids, or from virulent or non-virulent pathogens. For this reason, the diagnosis is often used in combination with antibody based methods, i.e. IFAT [18], and PCR for specific detection.

Moreover its important use serological methods that measure antibody responses in serum samples and it's a not-lethal method [19].

Is essential to do a multi-parametrical study for reduce the disease risks both wild and farmed fish, correlating: the culture of the microorganism, the serological, live/dead staining method [20], PCR methods and environmental conditions with all management activities.

\section{References}

1. Ceschia G (1992) Principali patologie batteriche nell'acquicoltura italiana Bollettino Società Italiana di Patologia Ittica 10:21-29.

2. Giorgetti G, Ceschia G (1994) Pasteurellosis in the Mediterranean area: Experiences from Italy. 3rd International Marine Biotechnology Conference, Tromsoe, Norway, pp: 7-12.

3. Gauthier G, Lafay B, Ruimy R, Breittmayer V, Nicolas JL, et al. (1995) Small-subunit rRNA sequences and whole DNA relatedness concur for the reassignment of Pasteurella piscicida (Snieszko et al.) Janssen and Surgalla to the genus Photobacterium as Photobacterium damsela subsp. piscicida comb. nov. Int J Syst Bacteriol 4: 139-144.

4. Thyssen A, Grisez L, Van Houdt R, Ollevier F (1998) Phenotypic characterization of the marine pathogen Photobacterium damselae subsp. piscicida. Int J Sys Bacteriol 48: 1145-1151.

5. Osorio CR, Matthew DC, Toranzo AE, Barja JL, Romalde JL (1999) 16S rRNA Gene Sequence Analysis of Photobacterium damselae and Nested PCR Method for Rapid Detection of the Causative Agent of Fish Pasteurellosis. Appl Environ Microbiol 65: 2942-2946.

6. Ghittino C, Arfarà S, Prearo M (1993) La Pasteurellosi ittica in Grecia. Bollettino Società Italiana di Patologia Ittica 11:11-20.

7. Magariños B, Romalde JL, Barja JL, Toranzo AE (1994) Evidence of a dorman but infective state of the fish pathogen Pasteurella piscicida in seawater and sediment. Appl Environ Microbiol 60: 180-186.

8. Fouz B, Toranzo AE, Milàn M (2000) Evidence that water transmits the disease caused by the fish pathogen Photobacterium damselae subsp. damselae. $J$ Appl Microbiol 88: 531-535

9. Peeler EJ, Murray AG (2004) Disease interaction between farmed and wild fish populations. J Fish Biol 65: 321-322.

10. Mancuso M, Avendaño-Herrera R, Zaccone R, Toranzo AE, Magariños $B$ (2007) Evaluation of different DNA-based fingerprinting methods for typing Photobacterium damselae ssp. piscicida. Biol Res 40: 85-92.

11. Mancuso M, Basile V, Innella G, Marino F, Cavalieri S, et al. (2005) Mugil cephalus: un campanello d'allarme della comparsa di focolai di Pseudotubercolosi in Spigole allevate in gabbie off-shore. Biologia Marina Mediterranea 12: 195-197.

12. Johansen LH, Jensen I, Mikkelsen H, Bjørn PA, Jansen P, et al. (2011) Disease interaction and pathogens exchange between wild and farmed fish populations with special reference to Norway. Aquaculture 315: 167-186.

13. Serracca L, Prearo M, Rossini I, Battistini R, Giorgi I, et al. (2011) Presenza di Photobacterium damselae ssp. piscicida in cefali (Mugil cephalus e Liza aurata) - atti del XVII convegno nazionale SIPI 2011.

14. Prearo M, Bozzetta E, Bossù T, Castiglione F, Centoducati G, et al. (2010) Attivazione del primo network nazionale di ricerca sulla fotobatteriosi - Atti del XVI Convegno SIPI 2010.

15. Romalde JL (2002) Photobacterium damselae subsp. piscicida: an integrated view of a bacterial fish pathogen. Int Microbiol 5: 3-9.

16. Amagliani G, Omiccioli E, Andreoni F, Boiani R, Bianconi I, et al. (2009) Development of a multiplex PCR assay for Photobacterium damselae subsp. piscicida identification in fish samples. J Fish Dis 32: 645-653.

17. Crisafi F, Denaro R, Genovese M, Cappello S, Mancuso M, et al. (2011) Comparison of $16 \mathrm{SrDNA}$ and toxR genes as targets for detection of Vibrio anguillarum in Dicentrarchus labrax kidney and liver. Res Microbiol 162: 223230.

18. Zaccone R, Caruso G, Zampino D, Mancuso M, Genovese L, et al. (2004) Early detection of Vibrio anguillarum in waters: a challenge experience on Dicentrarchus labrax in microcosm. Actes of Aquaculture Europe 34: 849-850.

19. Zaccone R, Mancuso M (2008) First report on antibody response of Seriola dumerilii (Risso 1810) challenged with Listonella anguillarum. Fish Shellfish Immunol 25: 689-692.

20. Mancuso M. "Fotobatteriosi: studio di nuovi metodi rapidi di identificazione" Ph.D. Thesis. 2006. 